REVIEW ARTICLE

\title{
Timeline of Cross Finger Flap: From its Inception to its Future
}

\author{
Sourabh Shankar Chakraborty, DNB, MNAMS ${ }^{(1)}$, Sudeshna Acharya, MBBS $^{2}$ (i), Manojit Midya, \\ $M S, M C h^{3}$ and Ranjit Kumar Sahu, MS, MCh, FCLS ${ }^{*}$ (D)
}

\author{
${ }^{1}$ Senior Resident, Department of Burns and Plastic Surgery, All India Institute of Medical Sciences, \\ Jodhpur, Rajasthan, India \\ ${ }^{2}$ Medical Officer (Trauma and Emergency), M R Bangur Hospital, Rajendra Prasad Colony, Tollygunge, \\ Kolkatta, West Bengal, India \\ ${ }^{3}$ Assistant Professor, Dr. Sampurnanand Medical College, Jodhpur, Rajasthan, India \\ ${ }^{4}$ Associate Professor, Department of Burns and Plastic Surgery, All India Institute of Medical Sciences, \\ Bhubaneswar, Odisha, India
}

*Corresponding author: Dr. Ranjit Kumar Sahu, MS, MCh, FCLS, Associate Professor, Department of Burns and Plastic Surgery, All India Institute of Medical Sciences, Bhubaneswar, Odisha, 751019, India, Tel: +91- 9937380273

\begin{abstract}
Since the first description of the cross-finger flap in 1950 for finger injury defect cover, over the last 70 years it has been tremendously explored and has underwent innumerable refinements and modifications. Whether used alone or in combination with other flaps for the reconstruction of finger defects, traumatic or non-traumatic, cross finger flap has proven its worth as a workhorse for finger reconstruction. Despite a handful of innate disadvantages, it has given excellent sensory, functional, and aesthetic outcomes in vast majority of studies. This article has been an attempt to reveal the entire rich journey and inexhaustible history of cross finger flap. With such a grandiose potential, it only seems that the cross finger flap will be continuously evolving over time and keep serving mankind in better ways.
\end{abstract}

\section{Keywords}

Cross-finger flap, Fingertip reconstruction, Finger injuries, Transdigital flap, Heterodigital flap

\section{Introduction}

Critical defects of fingers with exposed tendon, bone or joint warrants early soft tissue cover. Over time, innumerable techniques have been described for reconstruction of various finger injuries and deformities. Among all of them the journey of "the cross finger flap" has been most consistent and rich. It is doubtful whether any other finger injury reconstruction modality had been explored to this extent and so many modi- fications introduced, as has been the cross finger flap. This article is an attempt to make us aware of the vast plethora of finger defects that have been successfully managed by cross finger flap, and have this flap as a valuable addition in our armamentarium for various finger reconstructions.

\section{Methods}

PubMed [MEDLINE] database was searched on August 2020 using the MeSH terms: "cross finger flap [MeSH Terms] OR heterodigital flap [MeSH Terms] OR transdigital flap [MeSH Terms] AND finger [MeSH Ter$\mathrm{ms}$ ] OR thumb [MeSH Terms] OR finger injuries [MeSH Terms] OR finger amputations [MeSH Terms] AND reconstruction [MeSH Terms]". Studies were limited to human, published in English language between 1946 to 2020. The titles and abstract were reviewed manually to identify appropriate studies. In cases of unclarity, full text was reviewed. References of appropriate articles were also screened to identify additional related studies not obtained from original search. Pre-determined inclusion and exclusion criteria (Table 1) were applied to the search result to identify relevant citations.

\section{Results}

The PubMed search produced 1926 results. After title and abstract review of primary search and referen- 
Table 1: Inclusion and Exclusion Criteria.

\section{Inclusion criteria:}

1. Original article, Comparative study, Case report, Case series

2. Two-staged heterodigital or standard cross finger flap or modified cross finger flap.

\section{Exclusion criteria:}

1. Review article.

2. Any heterodigital flap based on neurovascular pedicle (proper digital artery) that did not had any intermediate syndactylised stage.

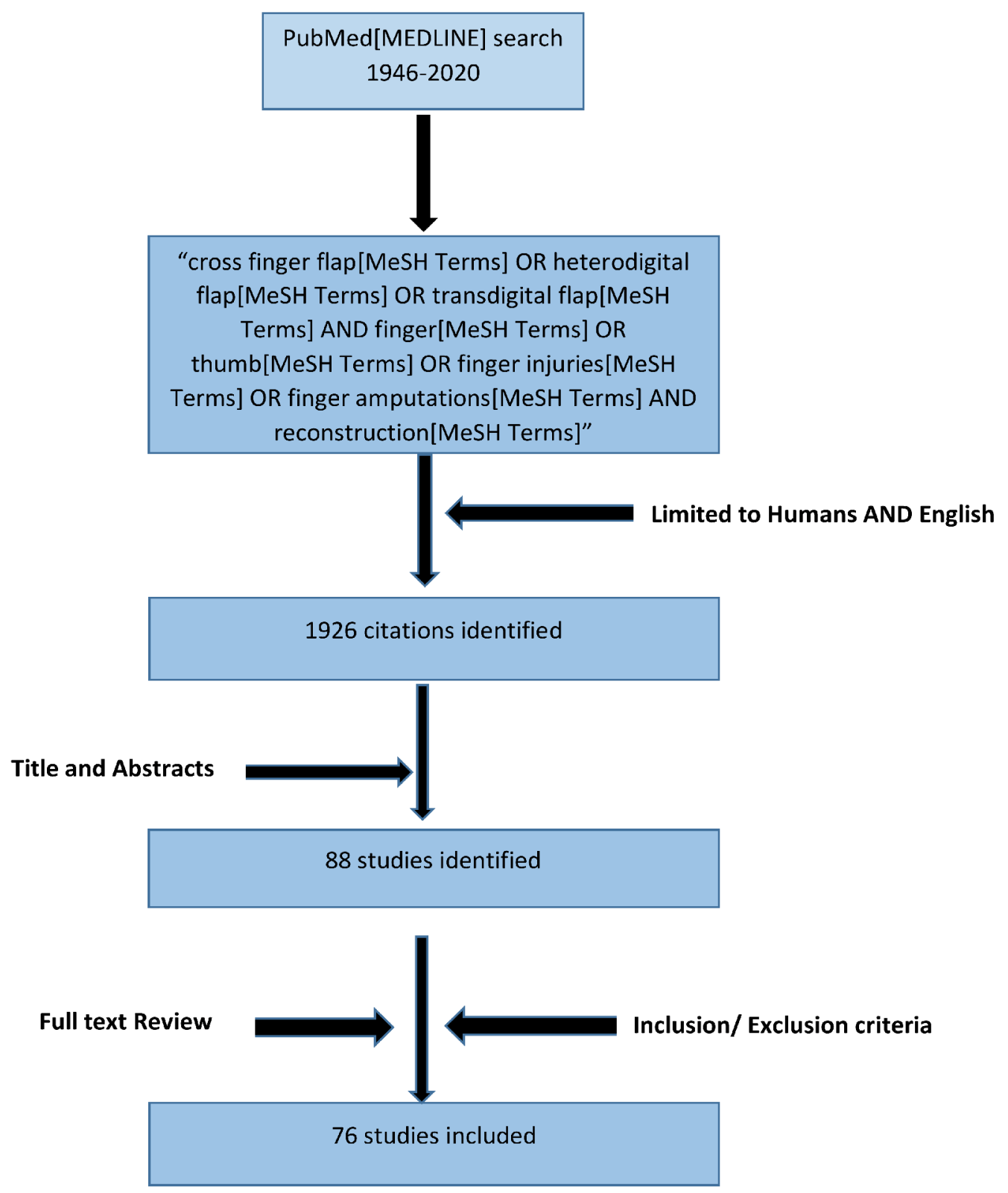

Figure 1: Flow chart of literature search.

ces, and applying the inclusion/exclusion criteria, 76 citations were identified (Figure 1), that went full text review and have been summarized as following (Table 2).

\section{Discussion}

\section{The beginning}

The earliest report of using trans-digital flap repair that could be found in literature was done in a series of 6 cases, by Gurdin and Pangman in 1950 [1] for finger injuries, as a two staged procedure. They used it when there was exposed bone or tendon, defect size was not very extensive, and donor finger was uninjured. They divided the flap at an interval of 2-3 weeks and reported no flap loss. However, it was Cronin [2] who first used the term cross finger flap in 1951. In the same year, Horn [3] reported excellent to good follow up result in 9 out of 10 cross finger flaps performed for traumatic amputation of distal phalanx and in two cases of extensive pulp loss. He also published the surgical principles 
Table 2: Chronology of evolution of cross-finger flap with its variants.

\begin{tabular}{|c|c|c|c|c|}
\hline $\begin{array}{l}\text { Year of } \\
\text { introduction }\end{array}$ & $\begin{array}{l}\text { Author } \\
\text { who first } \\
\text { introduced }\end{array}$ & $\begin{array}{l}\text { Defect } \\
\text { characteristic }\end{array}$ & Flap introduced & Flap characteristic \\
\hline 1950 & Gurdin [1] & $\begin{array}{l}\text { Fingertip and } \\
\text { volar defect with } \\
\text { exposed bone or } \\
\text { tendon. }\end{array}$ & $\begin{array}{l}\text { Transdigital flap } \\
\text { or standard cross- } \\
\text { finger flap. }\end{array}$ & $\begin{array}{l}\text { Retrograde or transverse based, two-staged flap } \\
\text { from contiguous area of skin (dorsal/ lateral) on an } \\
\text { adjacent finger. Flap made is } 1 / 4^{\text {th }} \text { larger in addition } \\
\text { to defect size. Length-width ratio not to exceed } 3: 1\end{array}$ \\
\hline 1971 & $\begin{array}{l}\text { Alonso- } \\
\text { Artteda [17] }\end{array}$ & $\begin{array}{l}\text { Degloving injury } \\
\text { with distal phalanx } \\
\text { amputation }\end{array}$ & $\begin{array}{l}\text { Wrap around cross } \\
\text { finger flap }\end{array}$ & $\begin{array}{l}\text { Replantation of distal phalanx with cross finger } \\
\text { flap from adjacent finger, along with its ulnar } \\
\text { neurovascular bundle }\end{array}$ \\
\hline 1972 & $\begin{array}{l}\text { Wilkinson } \\
{[11]}\end{array}$ & Thumb pulp defect & $\begin{array}{l}\text { Radial nerve } \\
\text { innervated cross- } \\
\text { finger flap }\end{array}$ & $\begin{array}{l}\text { Flap of skin and subcutaneous tissue from dorsum } \\
\text { of proximal phalanx of index finger as a two- } \\
\text { staged procedure, while the superficial radial nerve } \\
\text { branches to the flap are transferred primarily. }\end{array}$ \\
\hline 1980 & Atasoy [14] & $\begin{array}{l}\text { Index fingertip } \\
\text { amputation }\end{array}$ & $\begin{array}{l}\text { Cross thumb to } \\
\text { index finger pedicle }\end{array}$ & $\begin{array}{l}\text { Proximally based full thickness dorsal flap from } \\
\text { proximal phalanx of thumb, superficial to paratenon. } \\
\text { Both dorsal sensory branches of thumb are } \\
\text { preserved. }\end{array}$ \\
\hline 1982 & Atasoy [28] & $\begin{array}{l}\text { Dorsal skin } \\
\text { avulsions and } \\
\text { extensor tendon } \\
\text { injuries, nail bed } \\
\text { defects }\end{array}$ & $\begin{array}{l}\text { Reversed } \\
\text { cross-finger } \\
\text { subcutaneous flap }\end{array}$ & $\begin{array}{l}\text { Subcutaneous tissue flap from middle/ proximal } \\
\text { phalanx of adjacent finger is used. The full- } \\
\text { thickness skin flap raised from donor area covers } \\
\text { the donor defect. }\end{array}$ \\
\hline 1983 & Atasoy [30] & Hook nail deformity & Antenna procedure & $\begin{array}{l}\text { Cross-finger flap stabilised with multiple small } \\
\text { K-wires in stage one }\end{array}$ \\
\hline 1983 & Cohen [20] & Fingertip defects & $\begin{array}{l}\text { Innervated cross- } \\
\text { finger flap }\end{array}$ & $\begin{array}{l}\text { Flap raised from dorsum of middle phalanx along } \\
\text { with its dorsal sensory nerve (distal to pedicle), } \\
\text { which is then co-apted with digital nerve in recipient } \\
\text { finger in stage one. }\end{array}$ \\
\hline 1985 & Robbins [31] & $\begin{array}{l}\text { Dorsal finger } \\
\text { defects }\end{array}$ & $\begin{array}{l}\text { De-epithelised } \\
\text { cross-finger flap }\end{array}$ & $\begin{array}{l}\text { Donor split thickness skin graft was completely } \\
\text { removed. Adipofacial flap is used in reversed } \\
\text { fashion }\end{array}$ \\
\hline 1985 & Vlastou [33] & Thumb defects & $\begin{array}{l}\text { Volar cross-finger } \\
\text { flap }\end{array}$ & $\begin{array}{l}\text { Volar skin and subcutaneous tissue of proximal } \\
\text { phalanx of middle finger is used as donor flap. }\end{array}$ \\
\hline 1986 & Yanai [34] & Thumb tip defect & $\begin{array}{l}\text { Narrow pedicled } \\
\text { cross-finger flap }\end{array}$ & $\begin{array}{l}\text { Flag shaped cross finger flap harvested from } \\
\text { dorsum of middle phalanx }\end{array}$ \\
\hline 1993 & Mutaf [38] & $\begin{array}{l}\text { Dorsal, volar, } \\
\text { transverse defects }\end{array}$ & $\begin{array}{l}\text { C-ring cross-finger } \\
\text { flap }\end{array}$ & $\begin{array}{l}\text { An axial pattern cross finger flap, based on one } \\
\text { digital vascular bundle, proximally or distally. } \\
\text { Includes entire dorsal and half of volar surface of } \\
\text { donor finger. }\end{array}$ \\
\hline 1995 & Lai [40] & $\begin{array}{l}\text { Dorsolateral, lateral } \\
\text { defect }\end{array}$ & $\begin{array}{l}\text { Reverse } \\
\text { digital artery } \\
\text { neurovascular } \\
\text { cross-finger flap }\end{array}$ & $\begin{array}{l}\text { Flap harvested from lateral side of proximal phalanx } \\
\text { nourished by distally based digital artery. Segment } \\
\text { of digital nerve dorsal branch within the flap is used } \\
\text { to bridge gap in recipient area }\end{array}$ \\
\hline 2000 & $\begin{array}{l}\text { Sabapathy } \\
{[45]}\end{array}$ & $\begin{array}{l}\text { Multi-digital } \\
\text { mutilating injuries }\end{array}$ & $\begin{array}{l}\text { Jumping cross- } \\
\text { finger flap }\end{array}$ & Flaps taken from non-adjacent fingers \\
\hline 2002 & Lassner [24] & Fingertip defects & $\begin{array}{l}\text { Bilaterally } \\
\text { innervated cross- } \\
\text { finger flap }\end{array}$ & $\begin{array}{l}\text { Both dorsal sensory branches of donor flap are co- } \\
\text { apted with nerve stump of traumatised finger in both } \\
\text { stages sequentially }\end{array}$ \\
\hline 2009 & $\begin{array}{l}\text { Tadiparthi } \\
{[49]}\end{array}$ & $\begin{array}{l}\text { Circumferential } \\
\text { defect of ring finger }\end{array}$ & Open book flap & $\begin{array}{l}\text { Dorsal skin flap from donor finger is used for volar } \\
\text { cover, and adipofascial flap from same finger for } \\
\text { dorsal cover }\end{array}$ \\
\hline 2010 & Moosa [50] & $\begin{array}{l}\text { Ring avulsion injury } \\
\text { (Adani type IV) }\end{array}$ & $\begin{array}{l}\text { Double cross-finger } \\
\text { flap }\end{array}$ & $\begin{array}{l}\text { Standard cross finger flap for volar cover of } \\
\text { recipient finger. Reversed cross finger flap from } \\
\text { different donor for dorsal cover. }\end{array}$ \\
\hline 2011 & Zhao [25] & $\begin{array}{l}\text { Venous congestion } \\
\text { post digital } \\
\text { replantation }\end{array}$ & $\begin{array}{l}\text { Proximally based } \\
\text { cross finger flap as } \\
\text { venous conduit }\end{array}$ & $\begin{array}{l}\text { Veins of congested replant were anastomosed with } \\
\text { proximally based flap from proximal phalanx of } \\
\text { adjacent finger }\end{array}$ \\
\hline
\end{tabular}




\begin{tabular}{|l|l|l|l|l|}
\hline 2013 & Feng [56] & $\begin{array}{l}\text { Distal fingertip } \\
\text { degloving injury }\end{array}$ & $\begin{array}{l}\text { Innervated pedicled } \\
\text { cross-finger flap }\end{array}$ & $\begin{array}{l}\text { Dorsal flap from middle phalanx, based on dorsal } \\
\text { branch of proper digital artery is raised. Dorsal } \\
\text { sensory branch of digital nerve within the flap is co- } \\
\text { apted with digital nerve stump of injured finger. }\end{array}$ \\
\hline 2018 & Chong [65] & $\begin{array}{l}\text { Dorsal or volar } \\
\text { finger defects }\end{array}$ & $\begin{array}{l}\text { Laterally based } \\
\text { cross-finger flap }\end{array}$ & $\begin{array}{l}\text { Flap elevated from middle/ proximal phalanx } \\
\text { pedicled over midlateral line. }\end{array}$ \\
\hline
\end{tabular}

of preparation of defect, atraumatic raising and tensionless insetting of flap, donor site grafting, adequate immobilisation and dressings, and flap division in 10-14 days. He suggested flap should be limited within joint flexion creases, and must not coincide with midline of palmar aspect of donor finger. He enumerated rheumatoid arthritis, Raynauds disease, Dupuytren's contracture and advanced age as absolute contraindications for flap repair.

Adding to the points of Horn, in 1952, Tempest [4] stressed the importance of fingertip repair to elude chronic infection, scar, pain and anaesthetic fingertip. He enumerated advantages of cross finger flap for fingertip repair, namely better durability than any other part's skin, sensory recovery. He was the first to mention that flap can be raised proximally, distally or longitudinally based. He advocated against use of volar skin, not to violate neurovascular bundle, and flap division to be done at 2-3 weeks. In 1957, in a series of 17 patients, Curtis [5] used cross finger flap for reconstruction of finger injuries with 100 percent successful surgical result. Apart from the principles proposed by previous authors, he added (1) Dividing a layer of oblique fascial fibres to gain more pedicle length laterally, and (2) To place skin graft over donor finger and pedicle so as to obtain minimum scar. Kislov and Kelly [6] presented series of 53 cases, who underwent cross finger flap for reconstruction of traumatic amputation, flexor skin avulsion, degloving of terminal digit, secondary repair of scarred amputation stumps, defect cover following flexor contracture release. 34 flaps had excellent results. They introduced immobilisation using Kirschner wire, which was passed from middle phalanx of recipient finger transversely to proximal phalanx of donor finger, protecting the extensor apparatus and neurovascular bundles. Period of immobilisation ranged from 7 to 16 days.

Hoskins in 1960, mentioned that in longer flaps a ratio of 1:3, width-to-length ratio, must be maintained, and the pedicle must be proximally raised on the donor digit [7]. In an ambitious attempt to compare the late results of fingertip reconstructions using cross finger, split or full thickness grafts, palmar flaps or abdominal pedicled flaps done in 235 patients, Sturman and Duran [8] found that cross finger flap had better sensory recovery (mean two-point discrimination $6 \mathrm{~mm}$ ), and lesser tenderness, cold intolerance and disability than other reconstruction modalities. In 1965, Smith and Bom [9] were the first to use esthesiometer to measure twopoint discrimination to evaluate sensory outcome in 17 out of 29 cross finger flaps used for fingertip recon- struction. Other measures used to assess outcome were sensibility to light pin-prick and touch, tip contour, sweating, mobility in donor and recipient fingers. In 1967, Thomson \& Sorokolit [10] published a follow up study, in which 75 fingertip amputations in children were reconstructed with cross finger flap. Clinical assessment of reconstructed fingertip in terms of hyperesthesia, cold intolerance, sensory recovery (using two point discrimination test), colour, scar over donor areas and complications were done. They concluded that better clinical results are obtained in children in comparison to adults undergoing cross finger flap, namely lesser altered sensation, no postoperative stiffness, better aesthetic outcomes. So they recommended to include all age groups as an indication for cross finger flap, which was limited to above 7 years of age in that era. Wilkinson [11] reported 2 cases where functional thumb pad was reconstructed using radial innervated cross finger flap from proximal phalanx of index finger. Artz and Posch [12] were first to use cross finger flap to treat congenital broad constricting band, with an atrophic distal phalanx, in 3 cases. However they cautioned its use in narrow bands, for which multiple Z-plasty technique is ideal. In 1979, Hamilton, et al. [13] presented a series of 3 cases where they successfully used cross toe flap cover.

In 1980, Atasoy [14], one of the greatest pioneer of finger reconstruction, used radially based flap from proximal phalanx of thumb to reconstruct index finger tip injuries in 10 patients. He cautioned to preserve the dorsal sensory branches of the thumb and to pin index finger to the thumb. Nicolai and Hentenaar [15] were the first to objectively measure the progress of sensory recovery in 51 cross finger flaps, in 1981, by measuring difference between two point discrimination of flap and corresponding area in contralateral digit. They concluded that maximum sensation reaches within one year and usually does not improves further. Younger patient achieve better recovery. But results are unpredictable in patients over age of 20 years.

After 35 years of its inception, Kappel and Burech [16] published their results of cross finger flap over more than 200 patients. Various subjective questioning and objective parameters for neurosensory, functional and aesthetic outcomes were assessed, and finally declared cross finger flap as an "established reconstructive procedure".

\section{The microvascular era}

In 1971, Alonso-Artteda [17] increased the umbrella of cross finger from mere defect cover to its use in re- 
plantation. He reported a case in which right hand ring finger degloving injury with distal phalanx amputation was replanted and a cross finger flap (from middle finger) along with its ulnar neurovascular bundle was used to wrap around the avulsed ring finger. The syndactyly thus resulted was released two weeks later. Normal length was restored with good sensation and mobility. He also suggested that with a bone graft combined with cross finger flap having one complete neurovascular bundle an amputated digit can be even lengthened. Joshi [18], in 1976, reported two cases of technically demanding two staged sensory cross finger flap. In first stage, a radially based flap elevated preserving the dorsal branch of volar digital nerve. In next stage, this branch is dissected out, isolated from main neurovascular pedicle of donor finger and transposed onto recipient finger during flap detachment. A two point discrimination test after 2 months ranged 5-9 mm. In 1982, Sorman reported a case in which viable distal phalanx tip of injured ring finger was transferred over amputee stump of middle finger [19]. Anastomosis was done between ulnar digital artery and nerve of tip of ring finger to corresponding artery and nerve of middle finger. Venae comitantes were left intact within the bridging skin pedicle, which was divided after 3 weeks. Thus length of amputated middle finger was restored.

In 1983, in an attempt to reconstruct 8 fingertip amputation, Cohen and Cronin used innervated cross finger flap [20]. In lines of Joshi they dissected out the dorsal sensory nerve from end which is distal to pedicle in donor finger, and the digital nerve (or a branch) in recipient finger. An epineural neurorrhaphy between them is performed during first stage of flap insetting. After mean follow up of 14.4 months 7 patients acquired average two-point discrimination of $4.8 \mathrm{~mm}$, as against in the control group who underwent standard cross finger flap, only 50 percent achieved a mean upto $9 \mathrm{~mm}$. However they warned its use for defect in proximal segment. Following footsteps of Cohen, in 1985, Sucur performed cross finger flap based on superficial terminal branch of radial sensory nerve for volar defect of thumb in 5 patients [21]. Walker, et al. [22] performed cross finger flap for 6 patients with thumb pulp loss and transposed the radial sensory branches of the flap to recipient finger in first stage itself, and followed for a mean of 3 years. Preblock and postblock (radial sensory nerve) sensibility testing of radial and ulnar sides of the flap suggested that active sensory axons present in flap inhibits the functional or anatomic neurotization of the transferred flap. This hypothesis was not previously found in man, but in experimental animals.

Another breakthrough in use of cross finger flap came when Martin [23] suggested use of reverse cross finger flap, not to cover a defect but as a vascularized vein graft carrier in 3 cases of Wolff class II \& III ring avulsion injuries by creating venous anastomoses dor- sally. Using the technique of Cohen, Lassner, et al. [24] performed innervated cross finger flap by coapting dorsal sensory branch of non-adjacent donor finger with contralateral nerve stump of injured finger in stage one. In addition they also coapted the adjacent donor nerve with the nearby nerve stump of traumatised finger in stage two during flap division. In this bilaterally innervated cross finger flaps they obtained far superior sensory recovery (average two-point discrimination of $3.6 \mathrm{~mm}$ ) in their case series of 15 patients with zone 2 \& 3 finger pulp amputation. In 2011, Zhao, et al. [25] presented a novel solution for venous congestion post digital replantation, which could not be conservatively managed, or by cross anastomosis, vein grafts, reanastomosis. They used proximally based cross finger flap as venous conduit in 10 such patients, in which 9 had successful results. In 2012, Wang, et al. [26] reported reconstruction of 18 degloving finger amputation using a combination of bilaterally innervated cross finger flap and a composite free flap from the dorsal aspect of second toe. All the cross finger and free flaps survived well. At mean follow up of 17 months, they assessed static two point discrimination (2PD), cold intolerance, range of motion and donor sites morbidity.

\section{Modifications}

Until 1982, cross finger flap was used only for reconstruction of amputated finger stump or volar defects. Taking inspiration from Pakiam [27], Atasoy introduced reversed cross finger subcutaneous flap for dorsal digital defect in series of 4 patients [28]. The thin full-thickness skin flap elevated from dorsum of middle or proximal phalanx of donor finger itself cover the donor defect, while the adipofascial tissue covers the recipient dorsal defect. Fejjal, et al. in 2008 [29] reported a case in which this flap was used to cover index finger dorsum defect, with successful results. Again Atasoy, et al. in 1983 [30], presented a series of 4 patients with hook nail deformity with a follow up of 1 to 4 years, which was corrected using cross finger flap. They named it "antenna" procedure, as it looks so due to multiple small K-wires used in first stage. Patients achieved upto $4-8 \mathrm{~mm}$ of two-point discrimination. In 1985, Robbins [31] used de-epithelised cross finger flaps in 10 patients with dorsal finger defect. Only difference from Atasoy's reverse cross finger flap was he completely removed the split skin graft. In the same year, Groenevelt, et al. [32] used cross finger flap from scarred skin of ring finger to cover exposed tendons following release of 21 palmar flexion contractures of little finger and 4 button hole deformity of PIP joint. All the flaps survived, were cosmetically favourable and showed no tendency to contract.

Vlastou, et al. in 1985 [33], introduced a rather radical modifications, when they performed volar cross finger flap using proximal phalanx of middle finger to cover thumb defects of 10 patients. They enumerated its advantages, namely better bulk, as well as tissue 
and colour match for thumb, comfortable positioning, very reliable, and decreased chances of contracture. The patients had no donor site morbidity, painful scar or contracture or decreased grip strength or adhesions. In 1986, Yanai, et al. [34] presented 4 cases of thumb tip reconstruction with flag shaped cross finger flap harvested from dorsum of middle phalanx with its pedicle raised from radial side of proximal phalanx, approx. $1 \mathrm{X}$ $0.5 \mathrm{~cm}$. All the flaps developed distal margin blistering, however none of them had necrosis and survived well. In 1988, Gault \& Quaba [35] established role of cross finger flap in primary management of 5 untidy flexor tendon injuries, with $60 \%$ excellent and $40 \%$ fair results as per Kleinert criteria. This was comparable to the results of zone $1 \& 2$ flexor injuries with soft tissue loss. Robbins in 1988, innovated "Jam Roll" flap for reconstruction of oblique fingertip amputation in a 15 year girl, using de-epithelised cross finger flap, and preferred it over a thenar flap for giving bulk [36]. In 1991, Harrison, et al. [37] successfully covered the volar defect after releasing Dupuytren's contracture in 15 patients, with a one stage cross finger flap, raised from dorsum of adjacent fingers proximal phalanx. They advocated maximum permissible width of $1 \mathrm{~cm}$ for primary closure of donor defect and to centre the pedicle in proximity to web space. Mutaf, et al. [38], in 1993 advocated a C-ring flap design, an axial pattern cross finger flap based on one digital vascular bundle either proximally or distally. They successfully used this innovated flap in 12 patients with various finger injuries. Two times size, wider rotation arc, excellent blood supply were the advantages over traditional cross finger flap.

After the introduction of reverse digital island flap by Sapp, et al. [39] in 1983 initially designed for homodigital use, in 1995, Lai, et al. [40] pioneered a bold modification, in which they harvested reverse digital artery neurovascular flap based on palmar digital arterial network, along with digital nerve dorsal branch sparing the radial digital nerve, from lateral aspect of donor finger to cover the soft tissue and nerve defect over adjacent injured finger. In lines with Lai, Germann, et al. [41] in 1997, successfully used reverse pedicle heterodigital cross finger island flap in 5 patients. 3 of them suffered congestion but eventually all of the flaps survived well. Following this, in 2007, Nuzumlali, et al. [42] presented the versatility of this midlateral reverse-flow digital artery cross finger flap to cover finger defects of 9 patients. They noted no complications and achieved a two point discrimination score of 3-4 $\mathrm{mm}$ in 2 years in 7 patients. They warned not to elevate the flap distal to middle of middle phalanx, and cover donor area with skin graft.

El-Khatib [43] in 1996, described elevation of adipofascial axial pattern cross finger flap with either side vascular pedicle, proximally or distally based, for finger defect cover in 15 patients. The following year, Spoke- vicus and Gupta [44] presented 2 cases in which they harvested innervated cross finger flap along with some extra subcuticular tissue from adjacent phalanx, which was used to cover nail bed defect in one case and in the other to provide bulk to the finger pulp. They reported no donor morbidity or flap necrosis. Sabapathy [45] made use of soft tissue from non-adjacent injured fingers to cover small defects in salvageable digits, in 5 cases of multi-digital mutilating injuries. They named it as "jumping" cross finger flap. Perks being replacement of like with like, and least amount of tissue is discarded. In 2000, Chakrabarty, et al. [46] performed two cross finger flaps from middle and proximal phalanx of middle finger to cover defect over index finger, sparing $1 \mathrm{~cm}$ of skin bridge over PIP joint and recorded almost negligible morbidity of donor finger in terms of mobility after 6 months of follow up. In 2004, Al-Qattan [47] reported the use of distally based adipofascial flaps for dorsal digital defects as cross finger and turnover flaps in series of 15 cases. In the subsequent year [48], he presented a comparative analysis, where de-epithelised cross finger flap done in 31 patients and turnover adipofascial flap was done in 42 patients, and reported that latter was better suited in children, elderly with joint diseases and multiple finger injuries.

Tadiparthi, et al. [49] increased the reach of cross finger flap far beyond imagination. To cover a medium sized circumferential defect of ring finger, they used skin flap form donor middle finger (for volar cover) and the adipofascial flap from same digit (for dorsal cover). They named it "open book" flap, and reported no immediate or post-operative complication or stiffness in their patient. Capitalising on this concept, in 2010, Moosa [50] introduced "double cross finger" flap. In the 22 cases of ring avulsion injury (Adani type IV), in middle or ring fingers, he performed 44 transdigital flaps from both adjacent donor fingers (longer cross finger flap to cover volar defect of recipient finger while shorter reverse cross finger flap from another donor to cover the dorsal defect). With very few complications of donor site, they achieved 9-11 mm of two-point discrimination and active range of motion of upto 70-80 degrees at MCPJ and 60-75 degrees at PIPJ.

Mishra and Manisundaram [51] described another modification where they raised a reverse flow skin flap from hemidorsum of donor finger to cover defects in 32 finger injuries. The limits are midlateral line, midline of dorsum of finger, distal interphalangeal joint and upto $2 \mathrm{~mm}$ of web space. It gives an advantage of lesser donor site morbidity, however lesser width is a limitation. Hahn, et al. [52] in 2010, in their series of 9 patients with long standing proximal interphalangeal joint contracture performed cross finger flap for defect cover and vigorous post-operative exercises, showed promising results. Ismail described use of an adipofascial fillet flap from a non-viable digit for reconstruction of adjacent finger 
defect in 2010 [53]. Shah used cross digital dorsal adipofascial flap for post thermal burn dorsal defect, in which paratenon was also damaged, in 2010 [54]. They reported no post-operative complications. Patil [55] performed distally based traditional cross finger flap to cover 27 amputation stumps in avulsion amputation and reported stable cover and full recovery of range of motion in donor finger after an average 13 months follow-up. They routinely designed the flap by planning in reverse and in none splintage was done. In 2013 Feng, et al. [56] performed cross finger flap based on dorsal branch of proper digital artery, located withing 5-7 $\mathrm{mm}$ distal to PIP joint at middle phalanx, for 18 cases of distal fingertip degloving injuries. They also coapted the dorsal branch of proper digital nerve with digital nerve stump of injured finger and used $1.5 \mathrm{~mm}$ K-wire fixation for 2 weeks immobility. They reported a mean static two-PD $6.3 \mathrm{~mm}$ at mean follow up of 20.5 months. They advocated its indication in distal fingertip degloving injuries with 2 to $6.5 \mathrm{~cm}$ defect size. The following year Tan, et al. [57] performed series of artery-only distal fingertip replantation, and augmented the venous outflow by insetting a trap door flap from adjacent donor finger with the de-epithelised area of amputee. 3 of the amputees survived after flap division in 2-3 weeks. In the same year Gopalakrishna [58] reported a case of ring finger avulsion that was salvaged by a double cross finger flap with satisfactory 25 year follow up results.

In 2016, reverse cross finger flap's indications, contraindications, technique, and post-operative management were described by Atasoy [59]. In 2017, Yang, et al. [60] described use of reversed cross finger fascial flap combined with $0.3 \mathrm{~cm}$ split-thickness toe nail bed graft for reconstruction of large defect of nail bed in 6 patients, with satisfactory results. In 2018, Li and Chen [61] presented a case report in which composite grafting of zone $1 \mathrm{~A}$ thumb tip amputation was performed. Without any vascular anastomosis the graft survived as cross finger subdermal pocketing into middle phalanx of middle finger was also done. In same year, Al-Qattan, et al. [62] presented case series with 4 patients, in which large defects of index or ring fingers were covered by two dorsal cross finger flaps (either traditional or reverse cross finger) using middle finger as single donor. They observed no postoperative complications. In donor finger mild stiffness at DIP joint and hyperpigmentation in all patients, blistering of grafted site in one patient, mild cold intolerance in two patients were reported. None developed any painful neuroma in their 7-8 months follow up period. Paterson [63] and Koch [64] had previously evaluated donor finger morbidity in their case series of 16 and 23 patients respectively who underwent cross finger flap, in terms of stiffness, cold intolerance, active and passive range of motion (ROM), pain, aesthesis, pinch grip strength etc.

Chong, et al. [65] performed laterally based cross finger flap for volar or dorsal soft tissue defects in 13 fingers. Flap was elevated from middle or proximal phalanx with pedicle over midlateral line (minimum pedicle width $5 \mathrm{~mm}$ ) and donor site primarily closed (maximum flap width $13 \mathrm{~mm}$ ). 11 of the flaps completely survived. They reported lesser donor site morbidity than conventional cross finger flap. In 2019, Gunasagaran, et al. [66] reported reconstruction of fingertip and nail bed post chemical burn, using cross finger flap and split thickness nail bed graft. Following footsteps of Sabapathy and Ismail, in 2019, Al-Qattan and Mohrij [67] reported 2 cases with crush injury of multiple fingers, where defects were covered using spare parts in cross finger fashion.

\section{The denouements}

The survivability of flap depends on neovascularisation. Clinical assessment of capillary filling after applying tourniquet to the donor finger was at times equivocal. In 1990, Hallock [68] showed first time successful use of laser doppler flowmetry as a noninvasive objective measurement of relative perfusion in cross finger flaps and concluded that using $50 \%$ flow criteria all flaps survived following division. In their article published in 2001, Steenlage [69] described the method of evaluating the capillary refill of the flap clinically to determine the correct time for division.

Nishikawa and Smith [70] performed cross finger flaps for 54 single fingertip volar defects. In this ambitious study done over 5 years, the outcomes were measured, first time, based on subjective questionnaire, timed capillary return \& surface temperature for vascularity, electrical conductance testing as a measure of sweating, objective tests for sensory recovery namely protective sensation to pin prick, hot and cold thresholds, static and moving two-point discrimination, Von Frey hair testing, moving light touch, vibration, voltage and current thresholds. For hand functions they used questionnaire, pinch, grip strengths, joint mobility, pick up testing and tactile gnosis. Woon [71] performed 31 cross finger flaps using dorsum of middle or index finger to reconstruct oblique defects of distal thumb, and after a mean follow up period of 137 days assessed 2PD, Semmes Weinstein pressure aesthesiometer testing, ROM, donor site morbidity. They also tabulated their excellent sensory recovery and compared with previous studies. In 2015 Rabarin, et al. [72] reported long term outcomes of cross finger flap performed in 28 patients for fingertip amputation. After a mean follow-up period of 19.7 years they evaluated various parameters- complications, pulp volume as a ratio of contralateral and reconstructed fingertip pulp on lateral X-rays, static 2PD and Semmes Weinstein monofilament test of reconstructed tip compared to contralateral fingertip, cold intolerance, presence of neuroma, patient satisfaction with visual analogue scale.

It took more than 30 years since the first description 
of innervated cross finger flap for someone to conclusively prove its better sensory results over traditional cross finger flap. Lee, et al. [73] conducted a large series of reconstruction of fingertip defects, in which 69 cases underwent innervated cross finger (neurorrhaphy was performed between pulp branch from proper digital nerve of donor finger and recipients sensory nerve, while rest 21 cases defect cover was done only with the opposite pulp tissue of adjacent finger. They reported that after 12 months of surgery mean two-point discrimination in non-innervated cross finger was $7.2 \mathrm{~mm}$, while in innervated cross finger flap was $4.6 \mathrm{~mm}$ which was statistically significant $(p=0.001)$. All flaps survived. Taking inspiration from Feng [56] and Lee [73], in 2014 Chen, et al. [74] published an article, comparing outcomes of 17 bilaterally innervated sensory cross finger flap and 28 non innervated cross finger flap, all of which were based on dorsal branch of digital artery, for fingertip degloving injuries. They reported significantly better static 2PD, cold intolerance, and pain of injured finger $(P<0.05)$ and lower incidence of neuromas in the innervated pedicled cross finger flap in comparison to non-innervated pedicled cross finger flap. By contrast the same parameters had no significant difference in the two groups in their donor fingers.

In 2013, Kumar and Segu [75], in their unexpected study, performed cross finger dorsal adipofascial flap in their 15 patients with various finger injuries and compared their aesthetic outcomes with standard cross finger flaps 6 months post-operatively. They reported that mobility and sensory recovery was similar to the standard cross finger flap but this flap was aesthetically superior and therefore increased the horizon of dorsal adipofascial cross finger flap to injuries beyond the dorsal defects. In their prospective study, Ekinci and Gubuz [76] evaluated the surgical and clinical outcomes of reversed cross finger subcutaneous flap in 25 patients with dorsal digital defects. 6 months postoperatively they recorded 2PD, ROM of donor and recipient fingers, cold intolerance and Quick Disabilities of the Arm, Shoulder and Hand (DASH) score. They concluded owing to minimal donor site morbidity, satisfactory sensory and functional results, easy applicability, this flap must be preferred in dorsal digital defects.

Surprisingly for almost 30 years palmar cross finger flap was totally silent until In 2014, Erken [77] performed volar cross finger flap from index finger for reconstruction of dorsal oblique and transverse amputations of thumb in 12 patients. They reported mean 2PD scores of $4.5 \mathrm{~mm}$ and $4.3 \mathrm{~mm}$ in reconstructed thumb tip and donor site respectively after a mean follow up of 28 months. They also achieved excellent range of motion of injured and donor fingers.

Kim [78] measured the long term outcomes of reverse digital artery cross finger flap done for defect cover over 11 failed index and little finger replants. In all ca- ses neurorrhaphy was performed between donor dorsal sensory branch and injured proper digital nerve stump of injured finger. All 11 flaps survived well. After a mean follow-up of 53 months mean static $2 P D$ was $5.3 \mathrm{~mm}$, none had any cold intolerance or dysesthesia. ROM of donor finger achieved satisfactorily.

\section{Conclusion}

Over the span of this precise 70 years, cross finger flap has proven its worth in successful treatment of various finger injuries, fingertip defects, amputee stump cover, dorsal defects, avulsion amputation, degloving injuries, nail bed defects and in replantation; to cover defects following contracture release, hook nail deformity correction. It has always shown promising neurosensory, functional and aesthetic outcomes. Undoubtedly it has become the workhorse of finger injury reconstruction. Although the advantages and its limitations go hand in hand, with advent of better technologies and our increasing understanding of anatomy and physiology of finger injuries, cross finger flap will be continually evolving. Only time will reveal what lies in the pandora box of this cross finger flap.

\section{Conflict of Interest}

The Authors declare that there is no conflict of interest.

\section{Funding}

This study received no grants.

\section{Informed Consent}

Not applicable.

\section{Acknowledgements}

None declared.

\section{Authors Contributions}

SSC: Study design, data acquisition, and analysis and interpretation of data. Manuscript preparation, drafting the article, revising it critically for important intellectual content and final approval of the version; SA: Literature search, study design, data collection. Revising it critically for important intellectual content and final approval of the version; MM: Literature search, study design, data collection, revising critically for important intellectual content and final approval of the version; RKS: Editing and revising the manuscript critically for important intellectual content writing, critical revision, and final approval of the version.

\section{References}

1. Gurdin M, Pangman WJ (1950) The repair of surface defects of fingers by trans-digital flaps. Plast Reconstr Surg 5: 368-371.

2. Cronin TD (1951) The cross finger flap: A new method of repair. Am Surg 17: 419-425. 
3. Horn JS (1951) The use of full thickness hand skin flaps in the reconstruction of injured fingers. Plast Reconstr Surg 7: 463-481.

4. Tempest MN (1952) Cross-finger flaps in the treatment of injuries to the fingertip. Plast Reconstr Surg 9: 205-222.

5. Curtis RM (1957) Cross-finger pedicle flap in hand surgery. Ann Surg 145: 650-655.

6. Kislov R, Kelly AP (1960) Cross-finger flaps in digital injuries with notes on Kirschner wire fixation. Plast Reconstr Surg Transplant Bull 25: 312-322.

7. Hoskins (1960) The versatile cross-finger pedicle flap. $J$ Bone \& Joint Surg 42: 261

8. Sturman MJ, Duran RJ (1963) Late results of finger-tip injuries. J Bone Joint Surg Am 45: 289-298.

9. Smith JR, Bom AF (1965) An evaluation of finger-tip reconstruction by cross-finger and palmar pedicle flap. Plast Reconstr Surg 35: 409-418.

10. Thomson HG, Sorokolit WT (1967) The cross-finger flap in children: A follow-up study. Plast Reconstr Surg 39: 482487.

11. Wilkinson TS (1972) Reconstruction of the thumb by radia nerve innervated cross-finger flap. South Med J 65: $992-$ 994

12. Artz TD, Posch JL (1973) Use of cross-finger flap for treatment of congenital broad constriction bands of the fingers. Plast Reconstr Surg 52: 645-647.

13. Hamilton RB, O'Brien BM, Morrison WA (1979) The cross toe flap. Br J Plast Surg 32: 213-216.

14. Atasoy $E$ (1980) The cross thumb to index finger pedicle. J Hand Surg Am 5: 572-574.

15. Nicolai JPA, Hentenaar G (1981) Sensation in cross-finger flaps. Hand 13: 12-16.

16. Kappel DA, Burech JG (1985) The cross-finger flap. An established reconstructive procedure. Hand Clin 1: 677683.

17. Alonso-Artieda M (1971) Reimplantation of an avulsed ring finger using a sensory cross-finger flap. Br J Plast Surg 24: 293-295.

18. Joshi BB (1976) A sensory cross-finger flap for use on the index finger. Plast Reconstr Surg 58: 210-213.

19. Sormann GW (1982) Microsurgical cross finger flap. Hand 14: $279-282$

20. Cohen BE, Cronin ED (1983) An innervated cross-finger flap for fingertip reconstruction. Plast Reconstr Surg 72: 688-697.

21. Sucur D, Radivojevic M (1985) Cross finger flap. A new technique. J Hand Surg 10: 425-429.

22. Walker MA, Hurley CB, May JW (1986) Radial nerve cross-finger flap differential nerve contribution in thumb reconstruction. J Hand Surg Am 11: 881-887.

23. Martin DL, Kaplan IB, Kleinert JM (1990) Use of a reverse cross-finger flap as a vascularized vein graft carrier in ring avulsion injuries. J Hand Surgery Am 15: 155-159.

24. Lassner F, Becker M, Berger A, Pallua N (2002) Sensory reconstruction of the fingertip using the bilaterally innervated sensory cross-finger flap. Plast Reconstr Surg 109: 988993.

25. Zhao J, Abdullah S, Li WJ, Appukuttan A, Tien H (2011)
A novel solution for venous congestion following digital replantation: A proximally based cross-finger flap. J Hand Surg Am 36: 1224-1230.

26. Wang B, Zhang X, Jiang W, Ma T, Li H, et al. (2012) Reconstruction of distally degloved fingers with a crossfinger flap and a composite-free flap from the dorsum of the second toe. J Hand Surg Am 37: 303-309.

27. Pakiam AJ (1978) The reversed dermis flap. Br J Plast Surg 31: 131-135.

28. Atasoy E (1982) Reversed cross-finger subcutaneous flap. J Hand Surg Am 7: 481-483.

29. Fejjal N, Belmir R, Mazouz SE, Gharib N, Abbassi A, et al. (2008) Reversed cross finger subcutaneous flap: A rapid way to cover finger defects. India J Plast Surg 41: 55-57.

30. Atasoy E, Godfrey A, Kalisman M (1983) The "antenna" procedure for the "hook-nail" deformity. J Hand Surg Am 8: 55-58.

31. Robbins TH (1985) The use of de-epithelialised cross-finger flaps for dorsal finger defects. Br J Plast Surg 38: 407-409.

32. Groenevelt F, Schoorl R (1985) Cross-finger flaps from scarred skin in burned hands. Br J Plast Surg 38: 187-189.

33. Vlastou C, Earle AS, Blanchard JM (1985) A palmar crossfinger flap for coverage of thumb defects. J Hand Surg Am 10: $566-569$.

34. Yanai A, Nagata S, Mochizuki M, Tanaka H (1986) Reconstruction of the amputated thumb tip with a narrow pedicled cross-finger flap. Ann Plast Surg 16: 261-268.

35. Gault DT, Quaba AA (1988) The role of cross-finger flaps in the primary management of untidy flexor tendon injuries. $J$ Hand Surg $\mathrm{Br}$ 13: 62-65.

36. Robbins TH (1988) The "Jam Roll" flap for fingertip reconstruction. Plastic and Reconstructive Surgery 81: 109-111.

37. Harrison DH, Newton J (1991) Two flaps to resurface the basal flexion-crease of the finger area. J Hand Surg $\mathrm{Br} 16$ : 78-83.

38. Mutaf M, Sensoz O, Ustuner ET (1993) A new design of the cross-finger flap: The C-ring flap. $\mathrm{Br} \mathrm{J}$ Plast Surg 46: 97-104.

39. Sapp J, Allen RJ, Dupin C (1993) A reversed digital artery island flap for the treatment of fingertip injuries. J Hand Surg Am 18: 528-534.

40. Lai CS, Lin SD, Tsai CC, Tsai CW (1995) Reverse digital artery neurovascular cross-finger flap. J Hand Surg Am 20: 397-402.

41. Germann G, Rutschle S, Kania N, Raff T (1997) The reverse pedicled heterodigital cross-finger island flap. J Hand Surg $\mathrm{Br}$ 22: 25-29.

42. Nuzumlali ME, Ozturk K, Bayri O, Cepel S, Gurbuz C (2007) The versatile reverse-flow digital artery cross-finger flap. Tech Hand Up Extrem Surg 11: 259-261.

43. El-Khatib H (1996) Adipofascial axial pattern cross-finger flap. Plast Reconstr Surg 97: 850-853.

44. Spokevicius S, Gupta A (1997) The modified cross finger flap for finger pulp and nail bed reconstruction. J Hand Surg $\mathrm{Br}$ 22: 745-749.

45. Sabapathy SR, Mohan D, Bharathi RR (2000) 'Jumping' cross finger flaps: A useful technique for salvaging parts in mutilating hand injuries. Br J Plast Surg 53: 488-490. 
46. Chakrabarty KH, Kulkarni AA, Liddington M (2000) Monodigital double cross finger flaps. Br J Plast Surg 53: 266-267.

47. Al-Qattan MM (2004) Technical modifications and extended applications of the distally based adipofasical flap for dorsal digital defects. Ann Plast Surg 52: 168-173.

48. Al-Qattan MM (2005) De-epithelialized cross-finger flaps versus adipofascial turnover flaps for the reconstruction of small complex dorsal digital defects: A comparative analysis. J Hand Surg Am 30: 549-557.

49. Tadiparthi S, Akali A, Felberg L (2009) The "open book" flap: A heterodigital cross-finger skin flap and adipofascial flap for coverage of a circumferential soft tissue defect of a digit. J Hand Surg Eur Vol 34: 128-130.

50. Moosa AAA (2010) Double cross-finger flaps: A nove technique for management of ring avulsion injuries. Ann Plast Surg 64: 409-411.

51. Mishra S, Manisundaram S (2010) A reverse flow cross finger pedicle skin flap from hemidorsum of finger. J Plast Reconstr Aesthet Surg 63: 686-692.

52. Hahn SB, Kang HJ, Kang ES, Choi YR (2010) Correction of long standing proximal interphalangeal flexion contractures with cross finger flaps and vigorous postoperative exercises. Yonsei Med J 51: 574-578.

53. Ismail A, Athanasiadou M, Titley OG (2010) Spare parts surgery: The adipofascial cross finger flap. J Hand Surg Eur Vol 35: 239-240.

54. Shah SHA, Thrumurthy SG (2011) Re-establishing functionality and aesthetics after severe burns over the proximal interphalangeal joint using the cross-digital dorsa adipofascial flap. Burns 37: e16-e18.

55. Patil RK, Chavre S (2012) Distally based cross-finger flaps for amputation stumps in avulsion amputations. Indian $J$ Plast Surg 45: 504-511.

56. Feng SM, Gu JX, Liu HJ, Zhang NC, Pan JB, et al. (2013) Treatment of distal fingertip degloving injuries using a cross-finger flap based on the dorsal branch of the proper digital artery at the middle phalanx. J Reconstr Microsurg 29: $623-630$

57. Tan VH, Murugan A, Foo TL, Puhaindran ME (2014) Crossfinger dermal pocketing to augment venous outflow for distal fingertip replantation. Tech Hand Up Extrem Surg 18 131-134.

58. Gopalakrishna A (2014) Avulsion amputation of the ring finger managed by double cross finger flap: 25 years followup. Indian J Plast Surg 47: 444-446.

59. Atasoy E (2016) The reverse cross finger flap. J Hand Surg Am 41: 122-128.

60. Yang J, Wang T, Yu C, Gu Y, Jia X (2017) Reconstruction of large area defect of the nail bed by cross finger fascial flap combined with split-thickness toe nail bed graft. Medicine 96: e6048.

61. Li YS, Chen CY, Yang SW, Tarng YW (2018) Cross-finger subdermal pocketplasty as a salvage procedure for thumb tip replantation without vascular anastomosis: A case report. J Int Med Res 46: 3717-3723.

62. Al-Qattan OM, Almobarak AA, Al-Qattan MM (2018) Double cross finger flaps from the middle to the index or ring finger: A case series of 4 patients with an emphasis on donor finger morbidity. Int J Surg Case Rep 45: 107-111.

63. Paterson P, Titley OG, Nancarrow JD (2000) Donor finger morbidity in cross-finger flaps. Injury 31: 215-218.
64. Koch H, Kielnhofer A, Hubmer M, Scharnagl E (2005) Donor site morbidity in cross-finger flaps. Br J Plast Surg 58: 1131-1135.

65. Chong CW, Lin CH, Lin YT, Hsu CC, Chen SH (2018) Refining the cross-finger flap: Considerations of flap insetting, aesthetics and donor site morbidity. J Plast Reconstr Aesthet Sur 71: 566-572.

66. Gunasagaran J, Sian KS, Ahmad TS (2019) Nail bed and flap reconstructions for acute fingertip injuries - A case review and report of a chemical burn injury. J Orthop Surg 27: $1-6$.

67. Al-Qattan MM, Mohrij SA (2019) Spare-part fillet crossfinger flaps: A series of two cases. Int J Surg Case Rep 60: 221-223.

68. Hallock GG (1990) Preliminary assessment of laser Doppler flowmetry for determining timing of division of the crossfinger flap. J Hand Surg Am 15: 898-901.

69. Steenlage E, Blazar P, Wegner D, Pectol R (2001) A simple technique for testing the viability of cross-finger pedicle flaps. J Hand Surg Br 26: 76-77.

70. Nishikawa H, Smith PJ (1992) The recovery of sensation and function after cross finger flaps for fingertip injury. $J$ Hand Surg Br 17: 102-107.

71. Woon CY, Lee JY, Teoh LC (2008) Resurfacing hemipulp losses of the thumb: The cross finger flap revisited: Indications, technical refinements, outcomes, and longterm neurosensory recovery. Ann Plast Surg 61: 385-391.

72. Rabarin F, Cast YS, Jeudy J, Fouque PA, Cesari B, et al. (2016) Cross-finger flap for reconstruction of fingertip amputations: Long-term results. Orthop Traumatol Surg Res 102: S225-S228.

73. Lee NH, Pae WS, Roh SG, Oh KJ, Bae CS, et al. (2012) Innervated cross-finger pulp flap for reconstruction of the fingertip. Arch Plast Surg 39: 637-642.

74. Chen C, Tang P, Zhang L, Wang B (2014) Treatment of fingertip degloving injury using the bilaterally innervated sensory cross-finger flap. Ann Plast Surg 73: 645-651.

75. Kumar KM, Segu S (2013) Cross finger dorsal adipofascial flap-is it a aesthetically better variant? J Clin Diagn Res 7: 2527-2529.

76. Ekinci $Y$, Gubuz K (2020) Is the cross-finger flap a good option at the extensor zone defect? Jt Dis Relat Surg 31: 267-272.

77. Erken HY, Akmaz I, Takka S, Kiral A (2014) Reconstruction of the transverse and dorsal-oblique amputations of the distal thumb with volar cross-finger flap using the index finger. Journal of Hand Surgery (European Volume). 40: 392-400.

78. Kim DH, Seo KB, Lee SH, Lee HJ, Kang HJ (2018) Reverse digital artery cross-finger flap for reconstruction of failed finger replantation. J Orthop Surg 27: 1-6. 